\title{
The Role of Training of Goal Setting And Muscle Relaxation to Self Confidence of Swimmer Central Java Training Center 2016
}

\author{
$1^{\text {st }}$ Sungkowo \\ dept. Sport Coaching Education, \\ Faculty of Sport Science \\ Universitas Negeri Semarang \\ Semarang, Indonesia \\ sungkowo@mail.unnes.ac.id
}

\author{
$2^{\text {nd }}$ Kaswarganti Rahayu \\ dept. Sport Coaching Education, \\ Faculty of Sport Science \\ Universitas Negeri Semarang \\ Semarang, Indonesia \\ kaswarganti@gmail.com
}

\begin{abstract}
The purpose of this study is determine the role of training of goal setting and muscle relaxation against selfconfidence enhancer swimmer central java training center 2016. The population is swimmer Central Java Training Center 2016 in 2016, which amounted 8 people. Then the sampling technique is total sampling. The main data collection in this research is done by interview and additional data is done by using measuring instrument or self-confidence questionnaire. Qualitative data processing or interviewing is done by making informant answer category. While the quantitative data processing is done by testing the validity and reliability of the athlete self-confidence questionnaire. The results showed that the improvement of mental skills was followed by an increase in confidence of all swimmers. Increased confidence that occurs in Central Java Training Center 2016, swimmer can be seen to improve performance, swimmer proved can improve the record time at best time. But the target or goal setting time record on all athletes has not been able to achieve the goal setting they are targeting. Conclude that the intervention in the form of effective mental training in improving confidence to swimmer. For this study still apply the same mental training to all swimmer. We recommend for individual mental training programs. Subsequent research needs to adjust the giving of the form and the mental skill portion for each athlete.
\end{abstract}

Keywords- Goal Setting, Muscle Relaxation, Swimmer Confidence

\section{INTRODUCTION}

Goal setting is one good foundation for achieving success in mental skills training programs. Because that trainers and athletes can achieve success in both techniques, tactics and mental through the goal setting principle. The principle of goal setting is to help the athlete to pay attention to the right behavior to achieve success in the sport, increase the athlete's perseverance in various difficulties, strengthen efforts and achieve results in training and matches (Komarudin, 2013: 63).

In the sport of swimming achievement, athletes must have confidence because of self-confidence have a significant relationship to the performance improvement of athletes. The level of confidence is an indicator of success in every competition, the athlete can carry out his duties properly based on the belief in the abilities that exist in him. Athletes who have confidence will be consistent in the attitude and acting during practice and when competing. It is an athlete's mirror of consistency in its emotional aspect. The athlete who has the confidence will be able to perform interpretation, evaluate his own ability and can drive successful achievement and responsible for what is done and set (Komarudin, 2013: 68).

One of the most important discussions concerning self confidence is about the sources that become an athlete's confidence. By knowing the source of confidence, then the interested parties (trainers, coaches and others) can find out what interventions can be done to improve the athlete's confidence. Proper intervention will certainly have a positive effect on the performance show by the athlete (Juriana, 2012: 4).

Based on the description above, the authors are interested to conduct research entitled "The role of training goal setting and muscle relaxation toward self confidence improvement for swimmer of trainer center of Central java 2016". Based on the problems that have been found, then the formulation of the problem in this research as follows: What is the form of goal setting and Muscle Relaxation intervention training Can Improve Self Confidence for Swimmer of trainer center of Central java 2016 ?

\section{MATERIAL AND METHOD}

The research Methods is qualitative research, with research design before and after treatment.. A qualitative approach is an appropriate method to develop as a new approach in sports psychology and practice. Because experiences involving activities and body such as athletes are highly individual (Stelter, 2003). In addition to having different characteristics, the athlete's experience is also influenced by the specific situation he is facing. While some quantitative data as additional data or supporting data.

The research have two treatment : 1 . Goal setting, 2. Muscle relaxation. Additional data is done by using measuring instrument or self-confidence questionnaire

\section{A. Data Requred}

The data used for study consists of several things including: 1. Demographic and athlete performance data

2. Data about athlete's mental skills

3. Data on athletes' self-confidence 
The population is swimmer of trainer center of Central java 2016, which amounted to 8 people. Then the sampling technique is the total sampling.

\section{B. Data Collection Technique}

The main data collection in this research is done by interview for goal setting and muscle relaxation, additional data is done by using measuring instrument or self-confidence questionnaire.

Further questionnaire as additional data used in this study is a self-confidence questionnaire athlete pool adaptation of State Sport Confidence Inventory or SSCI. The grid of the measuring instrument used is as follows:.

TABLE I. GRID OF SELF-CONFIDENCE QUESTIONNAIRE (JURIANA,2012:38)

\begin{tabular}{|l|l|c|}
\hline \multicolumn{1}{|c|}{ Dimensions } & \multicolumn{1}{|c|}{ Definition } & Item Number \\
\hline $\begin{array}{l}\text { Exercise and } \\
\text { physical skills }\end{array}$ & $\begin{array}{l}\text { The athlete's belief or } \\
\text { trust that he or she } \\
\text { possesses the ability to } \\
\text { execute the required } \\
\text { physical skills to } \\
\text { demonstrate successful } \\
\text { attachment }\end{array}$ & $1,8,11$ \\
\hline $\begin{array}{l}\text { Cognitive } \\
\text { efficiency }\end{array}$ & $\begin{array}{l}\text { The athlete's beliefs or } \\
\text { beliefs that he or she is } \\
\text { able to focus, are able to } \\
\text { maintain concentration } \\
\text { and make decisions to } \\
\text { demonstrate success }\end{array}$ & $2,4,5,7,9$ \\
\hline Tenacity & $\begin{array}{l}\text { The athlete's confidence } \\
\text { or trust that he is able to } \\
\text { refocus after his } \\
\text { appearance, able to } \\
\text { immediately rise after a } \\
\text { bad performance, can } \\
\text { overcome the doubts of } \\
\text { problems and decline to } \\
\text { show a successful } \\
\text { performance. }\end{array}$ & $3,6,10,12,13$ \\
\hline
\end{tabular}

\section{Instrument Research}

The instrument of this research is self-athlete confidence questionnaire which has reliability of $r=0,921$ and validity ranged from 0,405 until 0,829 (Juriana, 2012: 39). It shows that the gauge is already consistent and it is appropriate to measure the confidence of the swimmer.

\section{RESULTS AND DISCUSSION}

In this chapter will describe the implementation and results of interventions that include: the overview of informants, the implementation of the intervention program and the outcome of the intervention program Informant's Overview

TABLE II. PRE TEST FOR BEST TIME

\begin{tabular}{|c|c|c|c|c|}
\hline No & Informant & Age & $\begin{array}{l}\text { Number Of } \\
\text { Competition }\end{array}$ & Best Time \\
\hline \multirow[t]{2}{*}{1} & \multirow[t]{2}{*}{ A } & \multirow[t]{2}{*}{14} & $50 \mathrm{M}$ freestyle & 00.27 .39 \\
\hline & & & $100 \mathrm{M}$ freestyle & 01.01 .07 \\
\hline \multirow[t]{2}{*}{2} & \multirow[t]{2}{*}{ B } & \multirow[t]{2}{*}{15} & $200 \mathrm{M}$ freestyle & 02.11 .39 \\
\hline & & & $400 \mathrm{M}$ freestyle & 04.39 .00 \\
\hline 3 & $\mathrm{C}$ & 16 & $200 \mathrm{M}$ butterfly & 02.30 .55 \\
\hline
\end{tabular}

\begin{tabular}{|c|c|c|c|c|}
\hline & & & $400 \mathrm{M}$ IM & 05.17 .00 \\
\hline 4 & \multirow{2}{*}{$\mathrm{D}$} & \multirow{2}{*}{19} & $\begin{array}{c}200 \mathrm{M} \text { breast } \\
\text { stroke }\end{array}$ & 02.40 .00 \\
\cline { 4 - 5 } & & & $\begin{array}{c}100 \mathrm{M} \text { breast } \\
\text { stroke }\end{array}$ & 01.16 .11 \\
\hline 5 & \multirow{2}{*}{$\mathrm{E}$} & 20 & $50 \mathrm{M}$ freestyle & 00.24 .25 \\
\cline { 4 - 5 } & & 20 & $200 \mathrm{M}$ freestyle & 01.56 .72 \\
\hline 6 & \multirow{F}{*}{$\mathrm{F}$ butterfly } & 02.05 .70 \\
\hline 7 & \multirow{2}{*}{} & 24 & $\begin{array}{c}50 \mathrm{M} \text { breast } \\
\text { stroke }\end{array}$ & 00.33 .43 \\
\cline { 4 - 5 } & & & $\begin{array}{c}100 \mathrm{M} \text { breast } \\
\text { stroke }\end{array}$ & 01.13 .50 \\
\hline 8 & \multirow{2}{*}{$\mathrm{H}$} & 25 & $100 \mathrm{M}$ back style & 01.01 .80 \\
\cline { 4 - 5 } & & & $50 \mathrm{M}$ back style & 00.28 .70 \\
\hline
\end{tabular}

In goal setting training, athletes are given the opportunity to write their targets twice (before explanation and after explanation of goal setting), then the researcher with the help and cooperation with the trainer performs the mental training that is muscle relaxation training. Exercise is done before or after meals.

The results of the implementation of this intervention program are divided into three: 1). changes in informant's mental skills before and after intervention, 2). changes in athletes' self-confidence before and after intervention, 3). change of time record for Goal setting.

\section{A. Changes in Informant Mental Skills}

After the training, seven of the eight swimmers experienced an improved goal setting skill, one athlete was an informant whose goal setting skills were lacking, but improved in moderate categories. In addition, relaxation exercises are the most frequent exercises to improve athlete's self-confidence and can decrease anxiety after his body relaxes. The anxiety then turns into self-confidence. Relaxed after relaxation makes the athlete more focused, his movements and swimming styles become more controlled and his body condition after relaxation becomes ready for use in swimming movements, and this makes him feel confident. Then the relaxed state after relaxation makes the athlete no longer has many disturbing thoughts. Here is an overview of skills change informants:

TABLE III. BEFORE AND AFTER FOR GOAL SETTING AND RELAXATION

\begin{tabular}{|c|c|c|c|c|}
\hline No & Informan & Before & & After \\
\hline 1 & A & $\begin{array}{l}\text { Goal setting } \\
\text { Less } \\
\text { Relaxation } \\
\text { Less }\end{array}$ & $=$ & $\begin{array}{l}\text { Goal setting = Good } \\
\text { Relaxation = Medium }\end{array}$ \\
\hline 2 & B & $\begin{array}{l}\text { Goal setting } \\
\text { Less } \\
\text { Relaxation } \\
\text { Less }\end{array}$ & $=$ & $\begin{array}{l}\text { Goal setting = Medium } \\
\text { Relaxation = Good }\end{array}$ \\
\hline 3 & $\mathrm{C}$ & $\begin{array}{l}\text { Goal setting } \\
\text { Less } \\
\text { Relaxation } \\
\text { Less }\end{array}$ & $=$ & $\begin{array}{l}\text { Goal setting = Good } \\
\text { Relaxation = Medium }\end{array}$ \\
\hline 4 & $\mathrm{D}$ & $\begin{array}{l}\text { Goal setting } \\
\text { Less } \\
\text { Relaxation } \\
\text { Less }\end{array}$ & $=$ & $\begin{array}{l}\text { Goal setting }=\text { Good } \\
\text { Relaxation }=\text { Good }\end{array}$ \\
\hline 5 & $\mathrm{E}$ & Goal setting & $=$ & Goal setting $=$ Good \\
\hline
\end{tabular}




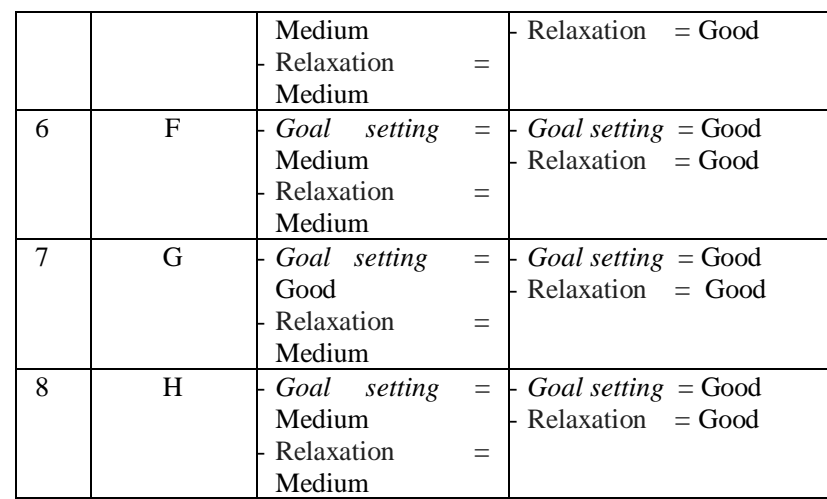

Based on self-confidence questionnaires, it is known that there is a change of confidence level before and after intervention. Confidence score after intervention is higher than pre-intervention score, more can be seen in table as follows:

TABLE IV. PRE TEST AND POST TEST SELF-CONFIDENCE

\begin{tabular}{|c|c|c|c|c|}
\hline No & $\begin{array}{c}\text { Inform } \\
\text { ant }\end{array}$ & Age & $\begin{array}{c}\text { Pre Test } \\
\text { Self- } \\
\text { Confidence }\end{array}$ & $\begin{array}{c}\text { Post Test } \\
\text { Self- } \\
\text { Confidence }\end{array}$ \\
\hline 1 & A & 14 thn & 86 & 105 \\
\hline 2 & B & 15 thn & 99 & 102 \\
\hline 3 & C & 16 thn & 93 & 95 \\
\hline 4 & D & 19 thn & 90 & 101 \\
\hline 5 & E & 20 thn & 92 & 94 \\
\hline 6 & F & 20 thn & 106 & 107 \\
\hline 7 & G & 24 thn & 113 & 115 \\
\hline 8 & H & 25 thn & 101 & 111 \\
\hline
\end{tabular}

\section{B. Change of Informant Time Record}

Time Based on the results of the PON (national sports week) of September 2016, it is known that after attending mental training, all athletes have not been able to reach the target of the prescribed time. But there are four athletes experiencing the best-time improvement in the primary number, 3 athletes having the best-time improvement on another number, and one athlete has not improved best-time. However, all athletes admit that they are better at competing after a mental training. Swimmers feel more energized but able to control themselves to stay calm, relaxed and concentrated. Furthermore, the acquisition of swimmers' time records to informants of this research is as follows:

TABLE V. CHANGE OF TIME RECORD

\begin{tabular}{|c|c|c|c|c|c|}
\hline No & Informant & $\begin{array}{c}\text { Competition } \\
\text { Number }\end{array}$ & $\begin{array}{c}\text { Best } \\
\text { Time }\end{array}$ & $\begin{array}{l}\text { Time } \\
\text { Target }\end{array}$ & $\begin{array}{c}\text { Results } \\
\text { of The } \\
\text { P0N }\end{array}$ \\
\hline \multirow[t]{2}{*}{1} & \multirow[t]{2}{*}{ A ** } & $\begin{array}{l}50 \mathrm{M} \\
\text { freestyle }\end{array}$ & 00.27 .39 & 00.26 .80 & 00.27 .68 \\
\hline & & $\begin{array}{l}100 \mathrm{M} \\
\text { freestyle }\end{array}$ & 01.01 .07 & 01.00 .50 & 01.00 .44 \\
\hline \multirow[t]{2}{*}{2} & \multirow[t]{2}{*}{ B *** } & $\begin{array}{l}200 \mathrm{M} \\
\text { freestyle }\end{array}$ & 02.11 .39 & 02.08 .00 & 02.10 .37 \\
\hline & & $\begin{array}{l}400 \mathrm{M} \\
\text { freestyle }\end{array}$ & 04.39 .00 & 04.36 .00 & 04.39 .00 \\
\hline \multirow[t]{2}{*}{3} & \multirow[t]{2}{*}{$\mathrm{C} * * *$} & $\begin{array}{l}200 \mathrm{M} \\
\text { butterfly }\end{array}$ & 02.30 .55 & 02.26 .00 & 02.27 .58 \\
\hline & & $400 \mathrm{M}$ IM & 05.17 .00 & 05.10 .00 & 05.28 .00 \\
\hline
\end{tabular}

\begin{tabular}{|c|c|c|c|c|c|}
\hline 4 & $\mathrm{D}^{* *}$ & $\begin{array}{c}200 \mathrm{M} \\
\text { breast stroke }\end{array}$ & 02.40 .00 & 02.37 .00 & 02.41 .00 \\
\cline { 3 - 6 } & $\begin{array}{c}100 \mathrm{M} \\
\text { breast stroke }\end{array}$ & 01.16 .11 & 01.14 .07 & 01.15 .83 \\
\hline 5 & $\mathrm{E}$ & $\begin{array}{l}50 \mathrm{M} \\
\text { freestyle }\end{array}$ & 00.24 .25 & 00.23 .90 & 00.24 .70 \\
\hline & $\begin{array}{l}200 \mathrm{M} \\
\text { freestyle }\end{array}$ & 01.56 .72 & 01.53 .80 & 01.58 .18 \\
\hline 6 & $\mathrm{~F}^{* * *}$ & $\begin{array}{l}200 \mathrm{M} \\
\text { butterfly }\end{array}$ & 02.05 .70 & 02.00 .00 & 02.04 .53 \\
\cline { 3 - 6 } & $\begin{array}{c}100 \mathrm{M} \\
\text { butterfly }\end{array}$ & 00.57 .02 & 00.55 .25 & 00.56 .94 \\
\hline 7 & $\mathrm{G}^{* * *}$ & $\begin{array}{c}50 \mathrm{M} \\
\text { breast stroke }\end{array}$ & 00.33 .43 & 00.32 .00 & 00.33 .38 \\
\cline { 3 - 6 } & $\begin{array}{c}100 \mathrm{M} \\
\text { breast stroke }\end{array}$ & 01.13 .50 & 01.12 .00 & 01.12 .44 \\
\hline 8 & $\mathrm{H}^{* *}$ & $\begin{array}{c}100 \mathrm{M} \\
\text { back style }\end{array}$ & 01.01 .80 & 00.58 .56 & 01.01 .58 \\
\cline { 3 - 6 } & $\begin{array}{c}50 \mathrm{M} \\
\text { backstyle }\end{array}$ & 00.28 .70 & 00.27 .20 & 00.27 .92 \\
\hline
\end{tabular}

Description: $* * *)$ has a time-lapse repair in the main style

**) encountered a timing improvement on the second style

In mental training has not been done specifically by the coach to accompany physical exercise in athletes so far. Clearly the reality of mental exercise in sport should be considered as important as physical exercise. Furthermore, mental training interventions conducted in this research are trying to contribute to the development of sports, especially in order to increase for Swimmer of trainer center of Central java 2016.

The athletes after implementing the intervention program or completing the training phase, then follow the race on PON XIX in Bandung West Java in 2016. This study limits the role of mental training in improving athlete's confidence. The results showed that the improvement of mental skills was followed by an increase in confidence of all swimmers.

Increased confidence that occurs for Swimmer of trainer center of Central java 2016 can be seen to improve performance, proved athletes can improve the record time at best time. Therefore, mental training should be done continuously by athletes in order to have a positive impact on performance improvement or improvement of time records at best time.

Then the target or goal setting time records on all athletes have not been able to achieve the goal setting they are targeting, according to researchers' observations of athletes have not been able to achieve goal setting because many factors that influence among them are very cold water conditions, weather that does not support especially frequent rain, health conditions, food consumption, geographical location of Bandung as a highland that resulted in athletes must struggle to adapt to the environment. Another factor is there are some athletes who keep track of time for targets or goal setting too high, which results in heavy athletes to be able to achieve the time already specified. But seven out of eight athletes can improve their best time.

Although the improvement in mental skills is followed by an increase in the confidence of all swimmers, but each swimmer feels certain mental exercises that play the most role in improving his confidence. This is very natural because experiences involving activities and bodies such as athletes are 
highly individual (individual defferences). In addition to having different characteristics, the athlete's experience is also influenced by the specific situation he is facing.

\section{CONCLUSION}

Conclude that the intervention in the form of effective mental training in improving confidence to swimmer. For this study still apply the same mental training to all swimmer. We recommend for individual mental training programs. Subsequent research needs to adjust the giving of the form and the mental skill portion for each athlete.

\section{REFERENCES}

[1] Ali Maksum. (2008). Psychology of sports theory and application. Surabaya: Publisher Unesa University Press

[2] Deputy for Sports Achievement, Ministry of Youth and Sport.(2011)

[3] Goldsmith, W. (2011). Swim coach brain. Australia: Playright Publishing and Swimming.

[4] Horn, TS. (2008). Advances in sport Psychology. Threth edition. Ohio: Human Kinetics, Inc.

[5] Juriana. (2012). The role of mental training in improving self confidence Ragunan school athlete. . Thesis. Depok: Faculty of Psychology Graduate Program

[6] Kartono.,Kartini \& Gulo,Dali. (2000). Psychology Dictionary. Bandung: Publisher Pioneer Jaya
[7] Komarudin. (2013). Psychology of mental exercise in competitive sports. Bandung: Bandung: PT Remaja Rosdakarya Offset press.

[8] Komarudin. (2015). Psychology of mental exercise exercise in competitive sports..Revised edition, Bandung: PT Remaja Rosdakarya Offset press.

[9] Middleton,S,C.,Marsh, HB., Martin, AJ.,Richards, G.E., Perry, C. (2001). Discovering mental toughness: A qualitative study of mental toughness in elite athlete. Journal of sport and exercises psychology. Australia: University of Western Sydney.

[10] Morrison, KA. (1999). The examination of state sport confidence of secondary school boys and girls participating in coeducational and gender seperated physical education class. Thesis. Canada: Faculty of Education McGill University.

[11] Murphy,Shane (2005). The sport psych handbook, a complete guide to today' best mental training techniques. Human kinetics.

[12] Poerwandari, EK (2007). A qualitative approach to human behavior research. Depok: Institute for Measurement and Education of Psychology

[13] (PLSP3)

[14] Rushall, B.S (2008). Mental skills training for sport. Fourth edtion. California: Spring Valley.

[15] Setiadarma, M.P (2000). The basics of sports psychology.Jakarta: Pustaka Sinar Harapan.

[16] Setyobroto, S. (2005). Sport psychology. Jakarta : Percetakan Universitas Negeri Jakarta.

[17] Vealey, RS., Hayashi, S.W., Giacobbi, P, \& Garner-Holman, M. (1998). Sources of Sport Confidence: Comceptualization and Instrument Development. Jounal of sport and exercise psychology, 20,54-80. 